УДК 331.5

DOI: https://doi.org/10.32782/2415-8801/2021-4.4

Поліщук О.Ю.

кандидат економічних наук, доцент кафедри менеджменту, Рівненський державний гуманітарний університет

Поляк К.Ю.

кандидат економічних наук, доиент, доцент кафедри менеджменту,

Рівненський державний гуманітарний університет

\title{
УПРАВЛІННЯ РОЗВИТКОМ ПЕРСОНАЛУ
}

У статті розглянуто сучасні цілі розвитку персоналу, напрями розвитку персоналу, наведено деякі засади розвитку персоналу, такі як індивідуальність, зацікавленість підприємства і працівника в розвитку кар'сри, матеріальне стимулювання, моральне стимулювання, обов'язковість професійного росту, соціально-психологічний комфорт і об'єктивність. Особлива увага приділена стратегіям розвитку персоналу, адже необхідність підготовки персоналу, який здатний здійснити якісне вирішення широкого спектру завдань, обумовлює необхідність стратегії розвитку персоналом. Розглядаються ситуативна та системна стратегіi, а також їх складові частини. Розглянуто директивні, інтерактивні та особистісні методики розвитку персоналу, значна увага приділена видам та формам навчання персоналу. Розглянуто необхідність синхронізації детальних програм розвитку персоналу з основною стратегією бізнесу, адже синхронізація стратехії розвитку персоналу та стратехії розвитку підприємства - це те, 3 чого починається успішна програма управління розвитком персоналу в організації.

Ключові слова: управління розвитком персоналу, иілі розвитку персоналу, напрями розвитку персоналу, принципи розвитку персоналу, методика навчання персоналу, стратегії розвитку персоналу, система оцінювання розвитку персоналу, тренди розвитку персоналу.

\section{PERSONNEL DEVELOPMENT MANAGEMENT}

Polishchuk Olena, Poliak Kateryna Rivne State University of Humanities

The article considers the current goals of staff development, areas of staff development, some principles of staff development, namely: individuality, interest of the company and employee in career development, material incentives, moral incentives, compulsory professional growth, social and psychological comfort and objectivity. The process of personnel development management has many aspects, as evidenced by the large number of points of view and different management methods; they include professional growth, continuing education in the workplace, staff development, and renewal of human resource management methods, talent management and other combinations of these aspects. Particular attention is paid to staff development strategies. After all, the need to train staffs that are able to qualitatively solve a wide range of problems necessitates a strategy of staff development. Situational and system strategies, as well as their components, as a set of actions and a sequence of decisions to assess, analyze and develop the necessary system of influence on staff to ensure the achievement of the necessary overall competitive potential to implement the chosen development strategy. Directive, interactive and personal methods of personnel development are also highlighted. It is noted that the basis of directive methods is the interaction of the student with the mentor, instructor, teacher, coach. There are such methods as: lectures, seminars, mentoring, instruction, training, secondment. In turn, interactive methods are seen as the participation of staff in training, in which a large role is given to modern technological capabilities. Interactive methods are presented: adaptation of personnel in the organization, distance learning, online conferences and webinars, video lessons. And personal methods are based on self-education and self-training of staff. Considerable attention is also paid to the types and forms of staff training. The need to synchronize detailed personnel development programs with the main business strategy is considered. After all, a successful program of personnel development management in the organization starts from the synchronization of personnel development strategy and enterprise development strategy.

Keywords: personnel development management, personnel development goals, personnel development directions, personnel development principles, personnel training methods, personnel development strategies, personnel development assessment system, personnel development trends. 
Постановка проблеми. Сьогодні, коли впровадження у виробництво новітніх технологій набуває особливого значення, окрему увагу варто приділити адекватним методам управління розвитку персоналу. Вони повинні будуватись на прогресивних підходах до управління розвитком персоналом та враховувати можливості розширення компетенцій персоналу. Звичайно, питання управління розвитком персоналу - це питання, яке 3'явилось не сьогодні. Насправді, ще в Середньовіччі тодішні підприємці здійснювали перші спроби забезпечити ріст персоналу, тоді й зародилось професійне навчання. На тому етапі воно здійснювалось через наставників та внутрішньоцехові школи. На другому етапі, у XIX ст., власники фабрик були змушені наймати спеціалістів, які покращували відносини в колективі і мотивували людей працювати ефективніше, адже ї виробництва стикнулись із дефіцитом добре навчених і мотивованих працівників. Проте наукову основу управління розвитком персоналу отримало лише на початку XX ст. Ї̈̈ прийнято пов’язувати з теорією Ф. Тейлора «Наукова організація праці», в якій були викладені поради для підвищення продуктивності праці в декілька разів. Нині $\epsilon$ щонайменше чотири теорії, такі як класична теорія Тейлора, школа відносин Мейо, теорія випадковості Вудворда та системний підхід Вінера.

Сучасні компанії змушені розвивати своїх працівників, якщо вони націлені на зростання й підвищення ефективності діяльності, адже відомо, що якщо цього не робити, то люди швидко «вигорають», перестають бути зацікавленими в результатах праці і часто шукають нове місце роботи. Саме тому так важливо грамотно організувати процес управління розвитком персоналу, отже, управлінню розвитком персоналу присвячена стаття.

Аналіз останніх досліджень і публікацій. На нашу думку, основними науковими доробками, які стали фундаментом для формування теорії розвитку персоналу, а також вивчення аспектів управління розвитком персоналу, $\epsilon$ праці українських та зарубіжних учених, таких як О.Ю. Амосов, Н.Н. Белоногова [2], О.А. Грішнова, А.В. Денисова, І.В. Журавльов, Т.П. Збрицька [4], Г.О. Савченко [4], А.Я. Кібанов, А.М. Колот, Е.М. Лібанова, Д.П. Мельничук, О.Ф. Морозов, В.О. Гончар [6], О.Ф. Новікова, І.Л. Петрова, М.Д. Романюк, В.А. Савченко, Д.Г. Шушпанов. Однак, незважаючи на те, що питання управління розвитком персоналу перебуває під пильним поглядом науковців, все ж таки багато теоретичних питань перебувають на етапі становлення й вимагають подальшого розв'язання та комплексного дослідження.

Постановка завдання. Метою статті є обгрунтування необхідності управління розвитком персоналу, проведення теоретичного аналізу сутності управління розвитком персоналу в сучасних умовах, визначення методичних підходів до формування стратегії, окреслення плану програми управління розвитком персоналу в організації.

Виклад основного матеріалу дослідження. Поняття «розвиток персоналу» прийнято застосовувати для визначення сукупності заходів органів управління й дії посадових осіб, спрямованих на досягнення якісних та кількісних змін у кадровому складі.

Розвиток персоналу - це також комплекс заходів, що включає професійне навчання випускників шкіл, перепідготовку та підвищення кваліфікації кадрів, планування кар'єри персоналу організації. Метою розвитку персоналу є забезпечення організації добре підготовлених працівників згідно з іiі цілями та стратегією розвитку.

Розвиток персоналу - це процес, який потребує від працівників і організації взаємодії, що розширює знання, навички, здібності та настанови, які необхідні для вирішення поточних і стратегічних завдань.

Розвиток персоналу передбачає розширення індивідуальних можливостей i нахилів працівників 3 урахуванням зміни характеру діяльності, індивідуальних та виробничих цілей. Професійний розвиток персоналу - це процес, спрямований на реалізацію поставних цілей, перш за все на покращення виробничого потенціалу колективу [1].

Виділимо такі основні цілі процесу управління розвитком персоналу:

- забезпечення навчання, яке необхідне для того, щоби працівник міг якісно виконувати роботу на рівні компетенцій у поточних та майбутніх призначеннях;

- створення атмосфери, яка сприяє самореалізації особистості, ефективності та творчості;

- економія, що передбачає надання співробітникам можливості розвиватись, адже щоразу наймати працівників, які не будуть справлятись, щоби потім їх звільнити, дуже дорого для компанії; також дорого втрачати хороших працівників через неможливість кар'єрного та професійного зростання;

- розроблення життєздатних і значимих програм розвитку персоналу, що дає змогу персоналу працювати для досягнення цілей компанії та особистих цілей [5].

Можливими є декілька таких варіантів розвитку персоналу:

1) робота на новій посаді 3 розширеними обов'язками;

2) розподіл відповідальності за кінцевий результат між максимальною кількістю робочих місць;

3) повна реорганізація того, чим керує працівник;

4) робота за кордоном;

5) участь у масштабному проєкті. 
При цьому можна виділити такі засади розвитку персоналу.

1) Індивідуальність. Вона характеризується наявністю винахідливості під час планування розвитку кар'єри, оскільки не всі керівники і спеціалісти можуть відповідати поставленим вимогам.

2) Зацікавленість компанії і працівника в розвитку кар'єри. Перспективний розвиток виробництва, мотивація до розвитку кар'єри та інші фактори.

3) Матеріальне та моральне стимулювання. Фінансування розвитку кар'єри працівників.

4) Обов'язковість професійного росту. Підвищення кваліфікації, ріст професіоналізму, відповідне планування.

5) Соціально-психологічний комфорт. Соціальне визнання та зростання матеріального стану.

6) Об'єктивність. Виключення впливу суб' єктивних факторів з боку керівництва, яке планує розвиток кар'єри і контролює його [1].

Управління розвитком персоналу, як і сам розвиток персоналу, потребує постійної уваги та вдосконалення ділових і особистісних якостей працівників. Для цього прийнято впроваджувати певні дії, а однією з перших дій є розроблення стратегії розвитку персоналу.

На стадії розроблення стратегії керівник повинен визначити, яких результатів він чекає від працівників, які професійні та особисті якості потрібно розвивати.

Стратегія розвитку персоналу може бути ситуативною та системною. Ситуативна стратегія прив'язана до конкретної бізнес-задачі, і для iii реалізації прийнято проводити зовнішні тренінги. Для цього, наприклад, залучають тренера, а саме фрилансера або консалтингову компанію. Перевагою залучення тренера $є$ економія на затратах, проте немає гарантій якості наданих послуг. У другому випадку з консалтинговою компанією підписується договір, що гарантує якість послуг, проте це передбачає високі затрати.

За системної стратегії використовується напрям постійного навчання й розвитку персоналу всередині компанії. Завдяки такій стратегії працівники отримують навики без відриву від виробництва. Навчання організовується відділом кадрів або консалтинговою компанією. У першому випадку розраховують на індивідуальний підхід, проте потрібна матеріальна база. Другий варіант передбачає високі затрати, проте розраховують на професійність тренерів та нові методи розвитку.

Так, наприклад, щоб розрахувати, скільки працівників потрібно компанії, спеціалісти мають проаналізувати величезний масив даних, зокрема плани підприємства, витрати на навчання персоналу та заробітну плату, рівень плинності кадрів, стан речей в усіх підрозділах. Визначення потреби в кількості та якості персоналу - це складна мате- матична задача, яку розв'язують різними способами, в тому числі залучаючи експертів або використовуючи різні комп’ютерні моделі.

Отже, основними видами навчання персоналу $€$ такі:

1) підготовка персоналу;

2) перепідготовка персоналу;

3) підвищення кваліфікації персоналу.

Всі вони можуть бути як короткостроковими, так і довгостроковими, індивідуальними або груповими [7].

Короткострокові форми мають свої переваги, такі як вартість та економія часу. Проте результати не завжди є такими, на які розраховували. Довгострокове навчання вимагає більше витрат, але приносить більше користі. Індивідуальне навчання дає змогу приділити увагу кожному працівнику окремо та надати максимум інформації 3 огляду на особисті потреби. Групове навчання дає можливість практикувати роботу в команді.

Сьогодні є дуже багато методів навчання персоналу. Всі їх можна розділити на активні та пасивні. До пасивних відносять лекції і семінари, де сприйняття інформації залежить від бажання самого працівника, а активні методи, такі як ділова гра, мозковий штурм, потребують максимуму концентрації кожного респондента. Варто також враховувати, що навчання на робочому місці найчастіше допомагає закріпити матеріал на практиці, а заняття за межами компанії дають змогу вийти за рамки і вчать діяти в нестандартних ситуаціях [7].

Виділяють також директивні, інтерактивні та особистісні методики розвитку персоналу. В основі директивних методів лежить взаємодія учня 3 наставником, інструктором, викладачем, тренером. Це такі методи, як лекції, семінари, наставництво, інструктаж, тренінги, секондмент. Інтерактивні методи розглядають як участь персоналу в навчанні, за якого важлива роль відводиться сучасним технологічним можливостям. Інтерактивні методики представлені адаптацією персоналу в організації, дистанційним навчанням, онлайн-конференціями та вебінарами, відеоуроками. Особистісні методи засновані на самоосвіті і самонавчанні персоналу [2].

Для того щоб управління розвитком персоналу було успішним, необхідно зіставити основну стратегію розвитку компанії та стратегію розвитку персоналу й скласти план, а потім і програму управління розвитком персоналу організації.

Для цього спочатку потрібно визначити напрям розвитку компанії, щоб ввести в нього розвиток колективу. При цьому незалежно від того, якою $є$ стратегія розвитку компанії (завоювання нового ринку, підвищення конкурентоспроможності, розширення каналів збуту), важливо продумати те, як програма розвитку персоналу може підкріпити iii та допомогти реалізувати. Більшість компаній 
вибирає такі напрями, як необхідність розширення штату й підготовка кадрового резерву; зниження унікальності кадрів; збереження або створення корпоративної культури; підготовка нових працівників; збереження знань [8].

Висновки 3 проведеного дослідження. Хочеться ще раз відзначити, що розвиток будь-якої компанії залежить від кваліфікації персоналу, тому не варто економити, а головне, навчити людей вчитися.

Звичайно, після навчання логічним стає етап оцінювання ефективності. Ми рекомендуємо проводити це оцінювання в декілька етапів. Перш за все слід оцінити реакцію слухачів одразу по завершенню програми навчання. На другому етапі варто оцінити рівень кваліфікації персоналу до початку курсу та по його завершенню. Потім через деякий час пропонуємо звернути увагу на зміну поведінки працівника, а саме на те, чи почав він використовувати отримані знання на практиці. На завершальному етапі потрібно оцінити результат і зробити висновок після спостереження протягом не менше трьох місяців.

За правильного підходу навчання мотивує працівників, утримує їх від переходу в іншу компанію та залучає нових працівників. При цьому підприємство вирішує проблему недостатньої грамотності персоналу, адже сьогодні кожен працівник має свою ринкову ціну, яка формується 3 огляду на його освіту, знання та вміння.

\section{Список використаних джерел:}

1. Асалиев А.М., Мирзабалаева Ф.И., Алиева П.Р. Развитие трудового потенциала : учебное пособие. Москва : Инфра-M, 2020. 281 c. URL: https://studref.com/607486/ekonomika/razvitie_trudovogo_potentsiala (дата звернення: 6.09.2021).

2. Белоногова Н.Н. Развитие персонала: 3 кита системы обучения сотрудников. Аргументы и Факты. URL: https://aif.ru/boostbook/razvitie-personala.html (дата звернення: 04.09.2021).

3. Веснин В.Р. Управление человеческими ресурсами. Теория и практика : учебник. Москва : Проспект, 2014. 688 с.

4. Збрицька Т.П., Савченко Г.О. Управління розвитком персоналу : підручник. Одеса : Атлант, 2013. 427 с. URL: http://dspace.oneu.edu.ua/xmlui/handle/123456789/467?show=full (дата звернення: 10.08.2021).

5. Леонова Е.В. Как организовать управление развитием персонала. URL: https://hurma.work/ru/blog/kakorganizovat-upravlenie-razvitiem-personala (дата звернення: 05.09.2021).

6. Морозов О.Ф., Гончар В.О. Система управлінням розвитку персоналу підприємства. Ефективна економіка. 2017. № 1. C. 92-95.

7. Обучение персонала - залог успеха компании. URL: http://npp-ohrana.ru/obuchenie-personala-zalog-uspexakompanii (дата звернення: 05.09.2021).

8. План программы управления развитием персонала в организации. URL: https:/hr-elearning.ru/planprogrammy-upravleniya-razvitiem-personala (дата звернення: 04.09.2021).

\section{References:}

1. Asaliev A.M., Mirzabalaeva F.I., Alieva P.R. (2020) Development of labor potential: a textbook. Moscow: Infra-M, 281 p. Available at: https://studref.com/607486/ekonomika/razvitie_trudovogo_potentsiala (accessed 06 September 2021).

2. Belonogova N.N. Staff development: 3 whales of the employee training system. Arguments and Facts. Available at: https://aif.ru/boostbook/razvitie-personala.html (accessed 04 September 2021).

3. Vesnin V.R. (2014) Human resources management. Theory and practice: a textbook [Human resources management. Theory and practice: a textbook] Moscow: Prospect, 688 p. (in Russian)

4. Zbrytska T.P., Savchenko G.O. (2013) Personnel development management: a textbook. Odessa: Atlant, 427 p. Available at: http://dspace.oneu.edu.ua/xmlui/handle/123456789/467? show=full (accessed 10 August 2021).

5. Leonova E.V. How to organize personnel development management. Available at: https://hurma.work/ru/blog/ kak-organizovat-upravlenie-razvitiem-personala (accessed 05 September 2021).

6. Morozov O.F., Gonchar V.O. (2017) Enterprise personnel management system. Efficient economy, no. 1, pp. 92-95.

7. Staff training is the key to a company's success. Available at: http://npp-ohrana.ru/obuchenie-personala-zaloguspexa-kompanii (accessed 05 September 2021).

8. The plan of the program of management of development of the personnel in the organization. Available at: https://hr-elearning.ru/plan-programmy-upravleniya-razvitiem-personala (accessed 04 September 2021).

E-mail:Lena_pol@ukr.net 